\title{
Improving Natural Disaster Mitigation and Adaptation Using Geographic Literacy
}

\section{Arif Susanto}

arifzhibond@gmail.com

\section{Sumarmi}

sumarmi.fis@um.ac.id

\section{Singgih Susilo}

Universitas Negeri Malang, Singgih.susilo.fis@um.ac.id

Doi:10.5901/mjss.2016.v7n6p333

\begin{abstract}
The purpose of the study is to describe the implementation of geographic literacy in order to improve natural disaster mitigation and adaptation of the students. The study is Classroom Action Research (CAR) carried out in 2 (two) cycles; each cycle consisted of 2 (two) meetings. Each meeting consisted of planning, implementation, observation and reflection. The sources of data were the students' learning outcome, portfolios, and scrapbooks about disaster mitigation and adaptation. The data were analyzed and evaluated. The findings showed that there was significant increase in the students' natural disaster preparedness. Portfolio caused $6.72 \%$ increase while scrapbooks caused $3.44 \%$ increase in the students' natural disaster preparedness. It is expected that teachers use the findings of the study as reference to develop students' awareness towards natural disaster.
\end{abstract}

Keywords: natural disaster preparedness, model of learning, geographic literacy

\section{Introduction}

Indonesia is prone to natural disasters. It is beyond human nature to be able to either predict when and where natural disaster would take place or prevent it. The only thing human being can do is to minimize casualties. Unfortunately, Indonesian 's literacy knowledge is lacking. Being eye-witnesses of how much damage natural disaster may cause, Indonesian started to realize importance of natural disaster preparedness. It is imperative that Indonesian citizens, including students, know what to do when natural disaster struck.

Disaster literacy involves knowing which area is prone to natural disaster and whether area where one living is prone to natural disaster. Disaster literacy should be introduced as early as possible, for example being introduced at school, to improve the preparedness of students. It is expected that disaster literacy can minimize the impact caused by natural disaster. Having had knowledge about natural disaster literacy, students will be able to decide what they are supposed to do when natural disasters strike. There is correlation between natural disaster and geographical conditions. Therefore, geography is a suitable subject to introduce disaster literacy.

Geography teachers play important role in introducing disaster literacy. Geography is a branch of knowledge that studies the environment. It has pivotal role to improve students' knowledge about disaster and disaster relief. It should be the lesson where materials about disaster relief and disaster management are discussed. Disaster literacy may not be able to prevent natural disaster but it may minimize the negative impacts of natural disasters. Developing disaster literacy as early as possible is vital so that Indonesian people can help themselves and other people when natural disaster struck. The literacy may be developed in geography class.

Introducing disaster literacy in geography class can develop student's problem-solving abilities especially certain issues related to natural disaster and geography. Students will understand possible issues related to geography and natural disaster so that they can come up with solutions and eventually reduce the number of casualties. Bennet (1997) stated that "Literacy geographic is the ability to take the basic skills of geographic and use them to develop an understanding of the world in which we live. Geographic literacy involves attempting to understand concept through five fundamental themes: location, place, relationship, movement and regions." Based on the statement, it can be inferred 
that geographic literacy can be used to overcome any issues on our daily lives. Geographic literacy involves five fundamental concepts namely location, place, relationship, movement and region. It is expected that students' comprehension about the concepts allows them to use them to solve various issues they encounter on a daily basis.

Geographic literacy affects the everyday lives of students in the way that. Geography teachers can select which geographic issues closely related to their students' lives in order to support the improvement of geography teaching in the classroom. Geographic literacy enables both teachers and students to obtain information about the importance of studying geography both at schools and outside the school environment. Edelson (2011) mentioned that developing geographic literacy and studying geography may influence students motivation and behavior that allow them to learn independently as well as empower and recognize how much contribution geography has in everyday lives. It is pivotal to develop literacy since speaking, listening, reading and writing abilities are essential during knowledge-seeking process as well as develop geographic literacy.

A previous study conducted by Setyawan (2013) described that natural disaster mitigation and adaptation especially one related to flood of the senior high school students in Surakarta was good and the percentage was 52.12\%. It was a descriptive quantitative study analyzing the lesson plans developed by the geography teachers. Another data collection method was interview. Another study was conducted by Khairunnisak (2013) who concluded that the level of the students' natural disaster mitigation and adaptation was average and the percentage was $52.70 \%$. The data collection method was questionnaire. The study revealed that student's natural disaster mitigation and adaptation is still within average category or below $60 \%$. Researchers should come up with solutions to improve student's natural disaster mitigation and adaptation more particularly teaching strategies that develop student's disaster literacy.

Disaster literacy of SMA Ibrahimy Sukorejo students is quite low. They have yet been able to develop connection between what they learn at school and how to apply knowledge related to disaster literacy either at school or outside the school. The students should have sufficient level of disaster literacy and disaster preparedness Situbondo is one of the areas in Indonesia that is prone to natural disasters such as drought, floods, and earthquakes. Since different types of natural disaster may occur in Situbondo, locals should have knowledge related to disaster relief and natural disaster preparedness. One model of learning that improves disaster preparedness is disaster literacy model.

Literacy is one type of model of learning model that has been widely used in various disciplines. Subadriyah , et al (2013) described literacy as a conceptual framework that is used as reference for carrying out activities in the classroom or tutorials to improve skills related to critical thinking, speaking, reading, and writing so that one will develop ability in specific cognitive operations through writing, words, sentences, and the text; these are used as means of communications in order to meet the demands of modern society. As learning model, literacy is really suitable to develop student's critical thinking and decision-making ability. Geographic literacy is an alternative learning method for geography class.

Geographic literacy, as learning method, takes the demand of the globalization, current information and technology into account. It emphasizes on critical and reflective thinking to develop understanding about geographic concept. The learning model is an alternative learning model to develop natural disaster literacy and preparedness. Besides that, it develops positive attitude and motivation towards geography that is notorious for theoretical, monotonous subject.

Not only does the model introduce knowledge related to place, space, people and their interactions, but it also develop student's critical-thinking and problem-solving ability so that the students can solve real-life problems. Based on Novarlia (2013), geographic literacy is a current trend in social science class that is developed as the result of research and development. It is an alternative that develops student's knowledge about geography using the real issues as source of discussions.

Geographic literacy requires teachers to play role as motivator and facilitator. The purpose is to grasp geographical concept through certain materials discussed in the classroom. The classroom activities aim at discovery learning and critical-thinking instead of collecting facts. Students should find as many information as possible and discuss it with their classmates. The following procedures are problem-solving activities and reflection at the end of the class. As the facilitator and motivator, teachers should stimulate students to learn independently and develop their own understanding about certain geographical concepts.

\section{Methodology}

The study is a Clasroom Action Research (CAR) that consisted of 2 cycles and each cycle consisted of 2 meetings. The setting of the study is X IPS 1, a grade in SMA Ibrahimy Sukorejo located in Situbondo during the odd semester of the 2015/2016 academic year. The number of students was 32 students. The sources of data were the students, observers and documentation. The data were in the form of the students' scores for their portfolios and scrapbooks. The data were 
later analyzed and evaluated in order to draw some conclusions.

Procedures of Classroom Action Research (CAR) consist of planning, implementation, observation and reflection (Asrori: 2011). Planning refers to developing lesson plans, worksheets, observation sheets, learning scenario and assessment. The topics are disaster mitigation and adaptation. Implementation refers to carrying out the lesson using 4 syntaxes namely content driven-scope and sequence, content standard, performance standard, and assessment. Observation refers to gaining further information the learning situation and students' activities during the lesson. Reflection refers to evaluation towards the learning activities. The result of observation is analyzed for evaluation and discussed as the means of reflection and reference for the following cycle. The researcher did not make a lot of change between cycle I and II. The topic was the only difference between the first and the second cycle.

\section{Findings}

The study lasted between March and April 2016. The learning process involed pre-, whilst- and post-teaching. In the preteaching stage, the teachers made some preparation, greeted the students, prayed with the students and checked the attendance list. The teacher showed a picture describing natural disater and some data related to the natural disaster. The following activitiy was giving information about the learning purpose and classroom activities. Based on the observations, some students were late, did their homework in the classroom and only students sitting at the front rows askingquestions and giving response. In Cycle II, there were some improvements for example no student was late and more students actively participated during the learning activities by asking questions and giving response towards the teacher's explanation.

In the whilst-teaching stage, the teachers carried out geographic literacy model using 4 syntaxes. Syntax 1 is a contet driven-scope and sequence. It began by dividing the students into 8 heterogeneous groups so that each group had 4 members. The students should find some issues or problems related to natural disaster around Situbondo or Indonesia from some articles. They could find them from the internet, school library or used newspapers. The students discussed which issues they wanted to discuss in groups.

During syntax 2 or content standart, the teacher distributed the worksheet where the students should make potfolios at the first meeting and scrapbooks on the second meeting based on the topic they had chosen. The worksheets consisted of sets of instructions. The students filled out the worksheet in groups. They may ask the teacher anytime they needed. Once they finished their worksheets, each group selected one representative to present the result of their discussion in front of tge class.

During syntax 3 or performance standart, the students made presentation. The representatives from each group came to the front of the class and the remaining students listened to the presentation. During the presentations, the students may ask questions, add some more information or describe their disagreement towards the presentation. The audience may also help the presentes answering the questions. The teachers became observes and managed the discussions.

During syntax 4 or assessment, the teacher and observer evaluated the discussions. The teacher also made some clariffications about some of the misconceptions during the presentation. Rewards were given for the best presenters, and some students who actively participated during the class by giving their opinions, asking and answering questions. The teachers also encouraged the students to take active participation during the lesson. The teacher asked the students to submit their worksheets and gave scores.

During whilst-teaching stage, the teacher observed the learning activities dominated by the students who dominated the lesson in Cycle I. Some of the students became very quiet when they were asked to answer questions or during the presentation. These students were also difficult to work with. The relied on other students or the group leaders to do the assignment. In general, Cycle II was better than Cycle I. The students had already showed teamwork. The students who did not want to work in groups were told by the teacher. They were asked to work with their groups. The students were more active than the teachers since the teachers played a role as facilitator during the learning process.

During the post-teaching stage, the teacher drew some conclusions and asked which aspects of the materials the students had yet understood. The following activity was reflection where the students described their opinions about the lesson and gave suggestions for the following lesson. The final activity was praying.

During the reflection, most of the students were hesitant to state their opinions, describe what they had learned, their expectation and suggestions for the following meeting. They did not explain whether the material improved their knowledge about disaster relief and preparedness or not. The teacher decided to ask the students to write down their reflection in a piece of paper and would select some students to read it.

The portfolios and scrapbook helped the students develop some comprehension about natural disaster relief and 
preparedness. They should analyze particular type of natural disaster and procedures to minimize the damage and casualties. Table 1.1 discussed the percentage of using portfolio as learning activity in geographic literacy model of learning in Cycle I and II.

Table 1.1 Portfolio Score Percentage in Cycle I and II during the Implementation of Geographic Literacy

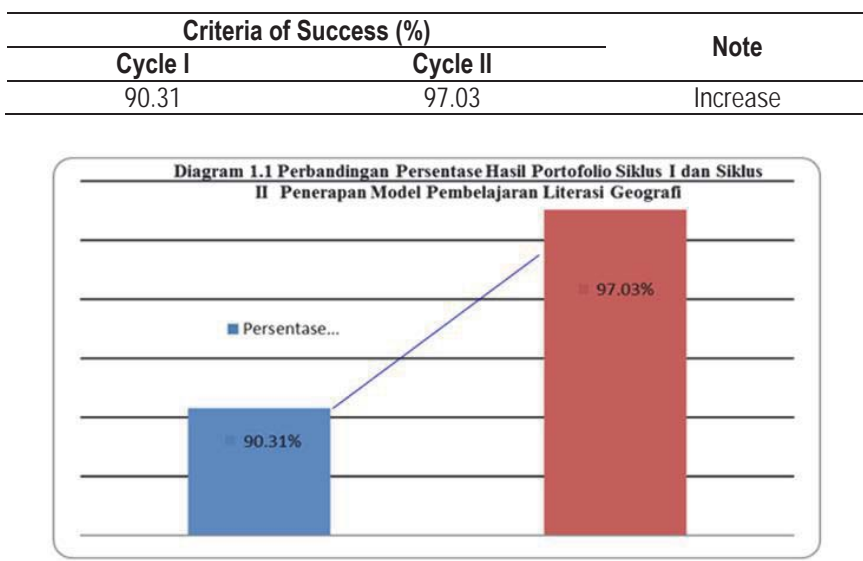

Diagram 1.1 Portfolio Percentage in Cycle I and II in the Implementation of Geographic Literacy

Table 1.1 and diagram 1.1 showed that there was $6.72 \%$ increase; the percentage was $90.31 \%$ in Cycle I and $97.03 \%$ in Cycle II. The percentages showed the students has had very good level of natural disaster literacy and preparedness after the implementation of geographic literacy. The student's creativity, analysis, experience and good literature also contributo the the increase. Besides portfolios, the teacher also asked the students to make scrapbooks. Table 1.2 discussed the percentage of using scrapbook as learning activity in geographic literacy model of learning in Cycle I and II.

Table 1.2 Scrapbook Score Percentage in Cycle I and II in the Implementation of Geographic Literacy

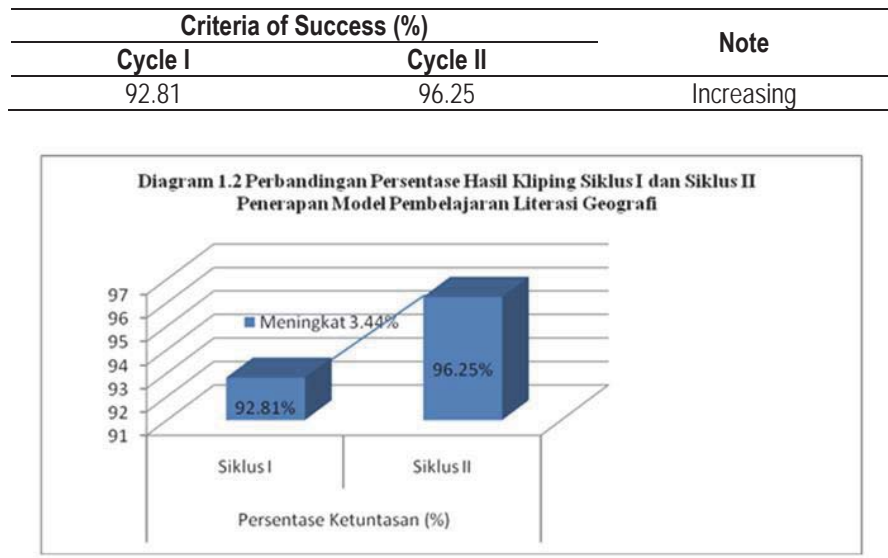

Diagram 1.2 Scrapbook Percentage in Cycle I and II in the Implementation of Geographic Literacy

Table 1.2 and diagram 1.2 showed there was $3.44 \%$ increase; the percentage was $92.81 \%$ in Cycle I and $96.25 \%$ in Cycle II. Similar to portfolio, scrapbook alo increase the student's knowledge about disaster preparedness. The students were very creative with their scrapbooks for example a group used the anonym LGBT for Letusan Gunung Bromo 
Tengger or Eruption of Mount Bromo and another group made colorful scrapbooks.

Based the reflection of Cycle I, there are some improvements the researchers should made. Some of the issues in Cycle I were (a) the students had yet been able to develop their own concepts; (b) the students found it difficult to draw conclusion from the discussions; (c) some students were late; (d) in some groups, there was only one student or the group leader who completed the assignments while the remaining group members were chatting or even sleeping.

Cycle II is better than Cycle I. More students gave their opinions, asked and answered questions from the teacher or other students. The students also gave some suggestions what the teacher should do in the following meeting. Furthermore, the students worked well in groups and no longer asked the group leader to finish the assignment. The classroom activities ran smoothly and the teacher role as the source of learning started to decrease.

\section{Discussions}

Based on the reflection stage, there is significant improvement in terms of the implementation of geographic literature, starting from planning, implementation to observation from Cycle I to Cycle II. The increase happened because the researchers successfully analyzed some weaknesses in Cycle I and made some improvement in Cycle II. The study is in line with Novarlia (2013), Misheck, et.al (2013), and Tuna (2015) that show the implementation of geographic literacy as learning model can improve student's knowledge in geography as well as their problem-solving skills particularly for issues related to geography.

An improve in the student's natural disaster mitigation and adaptationis also due to the fact that geographic literacy uses the student's experience to solve real-life issues as the platform. The students also make correlation between disaster mitigation and adaption, the materials discussed in the classroom and their daily lives to increase their awareness towards natural disaster. The model encourages meaningful learning because it allows the students to make their own decisions when natural disaster struck. The students practice how to save not only themselves but also other people.

The implementation of geographic literacy to impove SMA Ibrahimy Sukorejo students' natural disaster mitigation and adaptationis representated by the students' opinion towards mitigation and adaptation when disaster struck. The students thought that natural disaster is unpredictable but damage control should be carried out properly to avoid a lot of casualties. The students expect that they can have contributions to eliminate the damage natural disaster caused by telling other people what to do during earthquake.

As a learning model, geographic literacy can improve the students' learning outcome. Their learning outcome is an indicator of how much knowledge the students have about disaster mitigation and adaptation. The students have active participation and direct involvement in the learning activities. They are enthusiastic to participate in all of the activities taking place during all of the 4 syntaxes. In addition, it also gives more meaningful learning experience that lingers longer in the student's memory. Geographic literacy focuses on improving the student's comprehension as well as their ability to apply the learned concepts into their daily lives.

\section{Conclusion and Suggestions}

Based on the elaboration, it can be concluded that geographic literacy can improve one's knowledge and understanding about natural disaster preparedness. The students actively participate in the learning activities, making portfolios and scrapbooks about disaster mitigation and adaptation. There is an increase in the student's scores for the portfolio and scrapbook assignment from Cycle I to Cycle II. The students are aware of the importance of natural disaster mitigation and adaptationand willing to apply their knowledge about natural disaster mitigation and adaptationwhenever needed.

Based on the findings and discussions, it is suggested that (1) teachers use geographic literacy as an alternative model of learning and (2) schools apply the learning model to prepare students to minimize the negative impacts of natural disaster.

\section{References}

Asrori, Muhammad. 2011. Penelitian Tindakan Kelas. Bandung: CV Wacana Prima.

Bennett, W. M. 1997. Development Of Geographic Literacy in Students with Learning Disabilities. California: Journal RIEAUG98.

Edelson, Daniel C. 2011. Geo-literacy preparation far reaching decisions. (Online), (http://education.nationalgeographic.com/education/ news/geo-literacy-preparation-far-reaching-decisions/?ar_a=1), retrieved on December 20, 2015.

Khairunnisak, Novita Asriyanti. 2013. Geo-literacy Siswa Kelas VII SMP Muhammadiyah 5 Surakarta Tahun Ajaran 2012/2013. Artikel 
Publikasi. Surakarta. Universitas Muhammadiyah Surakarta. (Online). (http://eprints.ums.ac.id/25312/17/NASKAH_PUBLIKASI. pdf), retrieved on August 1, 2016

Novarlia, Irena. 2013. Model Pembelajaran Berbasis Literasi Geografi dalam Upaya Membangun Kecerdasaan Ruang. Disertasi tidak diterbitkan. Jakarta. UPI Press. (Online), (http://repository.upi.edu/2872/2/D_IPS_1009520), retrieved on September 28, 2015.

Misheck, Ezra, dan Mandoga. 2013. Geographic Literacy and World Knowledge amongst Open Distance Learning Students in Zimbabwe. Greener Journal of Educational Research. ISSN: 2276-7789. Vol. 3 (7), pp. 301-309, September 2013. (Online), (http://digilib.buse.ac.zw:8090/xmlui/handle/11196/592), retrieved on October 20, 2015.

Setyawan, Teguh. 2013. Melek Geografi SMA 7 Surakarta dan MA Al Islam di Kecamatan Serengan dalam Mengenal Bencana Banjir dan lingkungan. Artikel Publikasi. Surakarta. Universitas Muhammadiyah Surakarta. (Online). (http://eprints.ums.ac.id/25817/15/ jurnal_publikasi.pdf), retrieved on August 1, 2016.

Subadriyah, Triyono, dan Joharman. 2013. Penerapan Model Pembelajaran Literasi Dalam Peningkatan Membaca Kalimat Dengan Aksara Jawa Siswa Kelas IV Sekolah Dasar Negeri Kenoyojayan Tahun Ajaran 2012/2013. Jurnal Imu Pendidikan, (Online), (http://jurnal.fkip.uns.ac.id/index.php/pgsdkebumen/article/view/2407), retrieved on September 28, 2015.

Tuna, Fikret. 2015. What is the Level of Undergraduate Students' Geographic Literacy in Turkey Hacettepe Üniversitesi Eğitim Fakültesi Dergisi (H. U. Journal of Education) 30(2): 126-136(Nisan 2015). (Online), (http://www.efdergi.hacettepe.edu.tr/yonetim/icerik/ makaleler/12-published.pdf), retrieved on October 20, 2015. 